\title{
AN OPTIMIZATION MODEL FOR SELECTION OF IRDP SCHEMES*
}

\author{
P. KANNIAPPAN and $\mathrm{K}$. THANGAVEL \\ Department of Mathematics, \\ Gandhigram Rural Institute, \\ Gandhigram-624 302 \\ INDIA
}

\section{ABSTRACT}

The problem considered in this paper is to select various schemes under the Integrated Rural Development Program (IRDP) and to maximize the number of beneficiaries so as to optimize the annual income generated from each scheme. There are typical constraints prescribed by the government in the allocation of funds to several schemes from the budget outlay for IRDP each year. In this paper, with the help of the data drawn from the District Rural Development Agency of Dindigul Anna District, Tamil Nadu, India, we develop a linear programming model for maximizing the annual income generated from the schemes.

The paper was presented at the National Symposium on Optimization Techniques and Applications held at Thiagarajar College of Engineering, Madurai, India during June 18-19, 1992. 


\section{INTRODUCTION}

The aim of the IRDP of the Government of India[1] is to assist selected families below the poverty line in rural areas to cross this line by taking up self employment ventures, in order to uplift their socioeconomic conditions. Under this program, there are several schemes through which loans ${ }^{1}$ are sanctioned to the rural women, small farmers, marginal farmers and landless labourers. The number of schemes available under this program is in the range of $150-200$ or even more. Further, the program is aimed at achieving the stated objective by providing income generating assets including working capital, which are necessary to the target group families, through a package of assistance comprising subsidy ${ }^{2}$ and institutional credit.

\section{ABOUT IRDP}

IRDP has been under implementation since 1978-79. It was extended to the whole country from 2nd October, 1990, on the birthday of the Father of the nation, Mahatma Gandhi. Training of rural youth for self employment and development of women and children in rural areas are two important components of IRDP, which came into existence as the program evolved. The IRDP is a centrally sponsored scheme funded by the central and state governments on a 50:50 basis. IRDP implies an interdependent cooperative and comprehensive approach to rural development. IRDP helps to develop agriculture and in the establishment of rural industries which in turn facilitate the establishment of the required social infrastructure. This also helps to improve the literacy rate which ultimately improves the quality of life of rural poor[1].

3. DINDIGUL ANNA DISTRICT - A PROFILE

As per the 1991-92 census, the population of Dindigul Anna District is 17.8 million.

${ }^{1}$ Loan means it is a credit that the beneficiary has to repay to the government.

${ }^{2}$ Subsidy means the amount given as concession to a beneficiary. 
Further, more than $78 \%$ of the total population are living in villages. Hence the development of Anna District depends on the development of the rural areas. Keeping the welfare of the villagers in mind, the Government has introduced many welfare schemes for villagers. It is heartbreaking to note that more than $40 \%$ of villagers, in Dindigul Anna District, are landless and homeless agricultural labourers, who belong to $\mathrm{SC} / \mathrm{ST}^{1}$ (Scheduled caste/Scheduled Tribe). They earn their livelihood through agricultural work and their self employment.

\section{MATHEMATICAL MODEL FOR IRDP}

There are about 32 schemes through which loans are being distributed to villagers under the IRDP in Dindigul Anna District. After discussion with the District Rural Development Agency (DRDA) project officer, we realized that the allocation of funds and selection of beneficiaries for various schemes are not done by any systematic method. Since the IRDP is concerned with the socioeconomic upliftment of $78 \%$ of the people of the District, a systematic way of allocation of funds is necessary. Hence, realising the importance of this program, we have attempted to give a scientific approach (Mike Luck and Geoff Walsham[2]) to the problem of allocation of funds under several schemes and thereby increasing the effectiveness of the working of the program so as to improve the socioeconomic conditions of the rural poor.

In this paper, we have selected 20 schemes for which the data is given in Table 1. The data and other particulars were collected from the DRDA project officer directly.

${ }^{1} \mathrm{~A}$ class of people who are labeled as downtrodden on the basis of their socioeconomic conditions. 


\begin{tabular}{||l|l|l|l|l|l||}
\hline S.No & Scheme & Subsidy & Loan & $\begin{array}{l}\text { Total } \\
\text { Assis- } \\
\text { tance }\end{array}$ & $\begin{array}{l}\text { Annual } \\
\text { income }\end{array}$ \\
\hline 1. & Bullock with cart (Kankayam) & 3166 & 5334 & 9500 & 2700 \\
\hline 2. & Bullock with cart (Ordinary) & 2833 & 5667 & 8500 & 1500 \\
\hline 3. & Plough Bullock (Kankayam) & 1500 & 300 & 4500 & 1800 \\
\hline 4. & Plough Bullock (Ordinary) & 1166 & 2334 & 3500 & 1200 \\
\hline 5. & Goat & 666 & 1334 & 2000 & 1300 \\
\hline 6. & Milch Animal & 2333 & 4667 & 7000 & 4000 \\
\hline 7. & Poultry & 3300 & 6600 & 9900 & 3000 \\
\hline 8. & Sheep (Machery) & 2566 & 6134 & 8700 & 2000 \\
\hline 9. & Sheep (Ordinary) & 2400 & 5800 & 8200 & 1300 \\
\hline 10. & Barber & 1000 & 2000 & 3000 & 4600 \\
\hline 11. & Beekeeping & 666 & 1334 & 2000 & 1600 \\
\hline 12. & Pottery & 1333 & 2667 & 4000 & 1550 \\
\hline 13. & Cycle repair and hire shop & 1333 & 2667 & 4000 & 1400 \\
\hline 14. & Dhoby & 833 & 1667 & 2500 & 1100 \\
\hline 15. & Lime Kiln & 1866 & 3734 & 5600 & 2000 \\
\hline 16. & Motor Rewinding & 3050 & 6100 & 9150 & 4300 \\
\hline 17. & Tea stall & 1833 & 3667 & 5500 & 2700 \\
\hline 18. & Foot wear making & 2000 & 2000 & 4000 & 1700 \\
\hline 19. & Blacksmith & 1333 & 2667 & 4000 & 800 \\
\hline 20. & Carpentry & 1333 & 2667 & 4000 & 6000 \\
\hline \hline & & & & \\
\hline
\end{tabular}

Table 1

The selection of schemes/beneficiaries is to be made subject to several requirements. Some of the requirements/constraints as given by the DRDA office regarding various

${ }^{1}$ This column gives the annual income generated by each beneficiary by getting assistance under a particular scheme.

The three terms assistance, subsidy and loan are connected by the equation assistance $=$ subsidy + loan . 
schemes are given in Table 2 below.

\begin{tabular}{||l|l|c|}
\hline S1.no & Scheme & $\begin{array}{c}\text { Maximum number } \\
\text { of units }\end{array}$ \\
\hline 1. & Bullock with cart (Kankayam ${ }^{1}$ ) & 100 \\
\hline 2. & Bullock with cart (Ordinary) & 10 \\
\hline 3. & Plough Bullock (Kankayam) & 222 \\
\hline 4. & Plough Bullock (Ordinary) & 10 \\
\hline 5. & Goat & 358 \\
\hline 6. & Milch Animal & 1,127 \\
\hline 7. & Poultry & 140 \\
\hline 8. & Sheep (Machery) & 180 \\
\hline 9. & Sheep (Ordinary) & 90 \\
\hline 10. & Barber ${ }^{2}$ & 50 \\
\hline 11. & Beekeeping & 20 \\
\hline 12. & Pottery & 100 \\
\hline 13. & Cycle repair and hire shop & 150 \\
\hline 14. & Dhoby & 100 \\
\hline 15. & Lime Kiln & 5 \\
\hline 16. & Motor Rewinding & 50 \\
\hline 17. & Tea stall & 90 \\
\hline 18. & Foot wear making & 90 \\
\hline 19. & Blacksmith & 50 \\
\hline 20. & Carpentry & 50 \\
\hline & & 5 \\
\hline
\end{tabular}

\section{Table 2}

${ }^{1}$ a variety of bullock.

${ }^{2}$ in India, a person whose trade is shaving and men's hair-cutting.

${ }^{3}$ in India, a man whose trade is washing clothes. 
Further constraints on the problem are:

1. The budget outlay for the year 1991-92 is Rs. 1.8 million.

2. The total subsidy shall not exceed Rs. 6 million.

3. Total number of applications is limited to 2977.

The decision variables are defined as follows:

$x_{i}=$ the number of applicants to be selected under the scheme $i, i=1,2, \ldots, 20 . .(1)$.

The objective is to maximize the over all net profit of all the beneficiaries, who are selected under the schemes. That is, the aim is to maximize the total annual income of all beneficiaries. The idea is that if the annual income is maximized, then the socioeconomic conditions of the people (beneficiaries) will be improved.

This is given by

$$
\text { Maximize } z=\sum_{i=1}^{20} a_{i} x_{i}
$$

where $a_{i}$ is the profit by undertaking the $i^{\text {th }}$ scheme.

The constraints:

The constraints in this model are: the budget outlay of the government, the total subsidy and the other relating to the number of applications received from the people requiring assistance under different schemes which are given in Table $1 \ldots$ (3).

The model described by (1)-(3) is a linear programming problem with 20 variables and 23 constraints excluding the non negativity constraints (see Murthy [3]).

\section{RESULTS}

We have developed a software package in PASCAL to solve this linear programming 
model, in a PCIAT environment. The results obtained while running the software are given in Table 3.

\begin{tabular}{|c|c|c|}
\hline Name of the scheme & $\begin{array}{l}\text { Number of beneficiaries } \\
\text { to be selected }\end{array}$ & $\begin{array}{l}\text { Profit earned by the } \\
\text { beneficiaries }\end{array}$ \\
\hline Bullock with car (Kankayam) & 100 & $2,70,000$ \\
\hline Bullock with cart (Ordinary) & 10 & 15,000 \\
\hline Plough-Bullock (Kankayam) & 222 & $3,99,600$ \\
\hline Plough-Bullock (Ordinary) & 10 & 12,000 \\
\hline Goat & 358 & $4,65,400$ \\
\hline Milch Animal & 1,127 & $45,05,000$ \\
\hline Poultry (Broiler) & 140 & $4,20,000$ \\
\hline Sheep (Machery) & 180 & $3,60,000$ \\
\hline Sheep (Ordinary) & 90 & $1,27,000$ \\
\hline Barber & 50 & $2,30,000$ \\
\hline Bee-keeping & 20 & 32,000 \\
\hline Pottery & 100 & $1,55,000$ \\
\hline Cycle repair and hire & 150 & $2,10,000$ \\
\hline Dhobi & 31 & 34,100 \\
\hline Lime kiln & 5 & 10,000 \\
\hline Motor Rewinding & 5 & 21,500 \\
\hline Tea-stall & 70 & $1,89,000$ \\
\hline Foot wear making & 130 & $2,21,000$ \\
\hline Blacksmith & 20 & 16,000 \\
\hline Carpentry & 90 & $5,40,000$ \\
\hline TOTAL & 2,908 & $82,32,600$ \\
\hline
\end{tabular}

\section{Table 3}




\section{CONCLUSION}

As already mentioned in this paper, the data and other details have been gathered from the DRDA project officer and other connected people in that office.

Since the objective is to maximize the total annual income and there is a limitation on the assistance to milch animal (constraint number 6 in Table 2), it was to be expected that the allocation for milch animal would be at its upper limit.

The model does not assume the change in the environment such as price of milk, disease, drought etc. The input data in Table 1 will change over time and a periodic review of data is a must.

The first hand information regarding the feasibility of each scheme and the economic return form each scheme can be collected by interviewing the rural people who are participating in the schemes. Hence, the model can be improved further so as to give practical realistic solution.

\section{ACKNOWLEDGEMENT}

We would like to thank the referees for their comments in the presentation of this paper.

\section{REFERENCES}

[1] A manual - Integrated Rural Development programme - Department of Rural Development 1987.

[2] Mike Luck and Geoff Walsham, Operations Research Applications in Development Management Case Exercise book, Commonwealth Secretariat, 1987.

[3] Murthy, K.G., Linear Programming, John Wiley, New York, 1983. 